\title{
La mythologie nordique au bout des doigts
}

Dreams of Valhalla, une application pour tablette-PC produite à

l'Université de Strasbourg

\section{CpenEdition}

\section{Journals}

Édition électronique

URL : https://journals.openedition.org/rbnu/2032

DOI : $10.4000 /$ rbnu. 2032

ISSN : 2679-6104

Éditeur

Bibliothèque nationale et universitaire de Strasbourg

\section{Édition imprimée}

Date de publication : 1 novembre 2013

Pagination : 88-91

ISBN : 9782859230517

ISSN : 2109-2761

\section{Référence électronique}

"La mythologie nordique au bout des doigts », La Revue de la BNU [En ligne], 8 | 2013, mis en ligne le 01 novembre 2013, consulté le 20 mai 2021. URL : http://journals.openedition.org/rbnu/2032 ; DOI : https://doi.org/10.4000/rbnu.2032

\section{(c) (i) (2)(2)}

La Revue de la BNU est mise à disposition selon les termes de la Licence Creative Commons Attribution - Pas d'Utilisation Commerciale - Partage dans les Mêmes Conditions 4.0 International. 


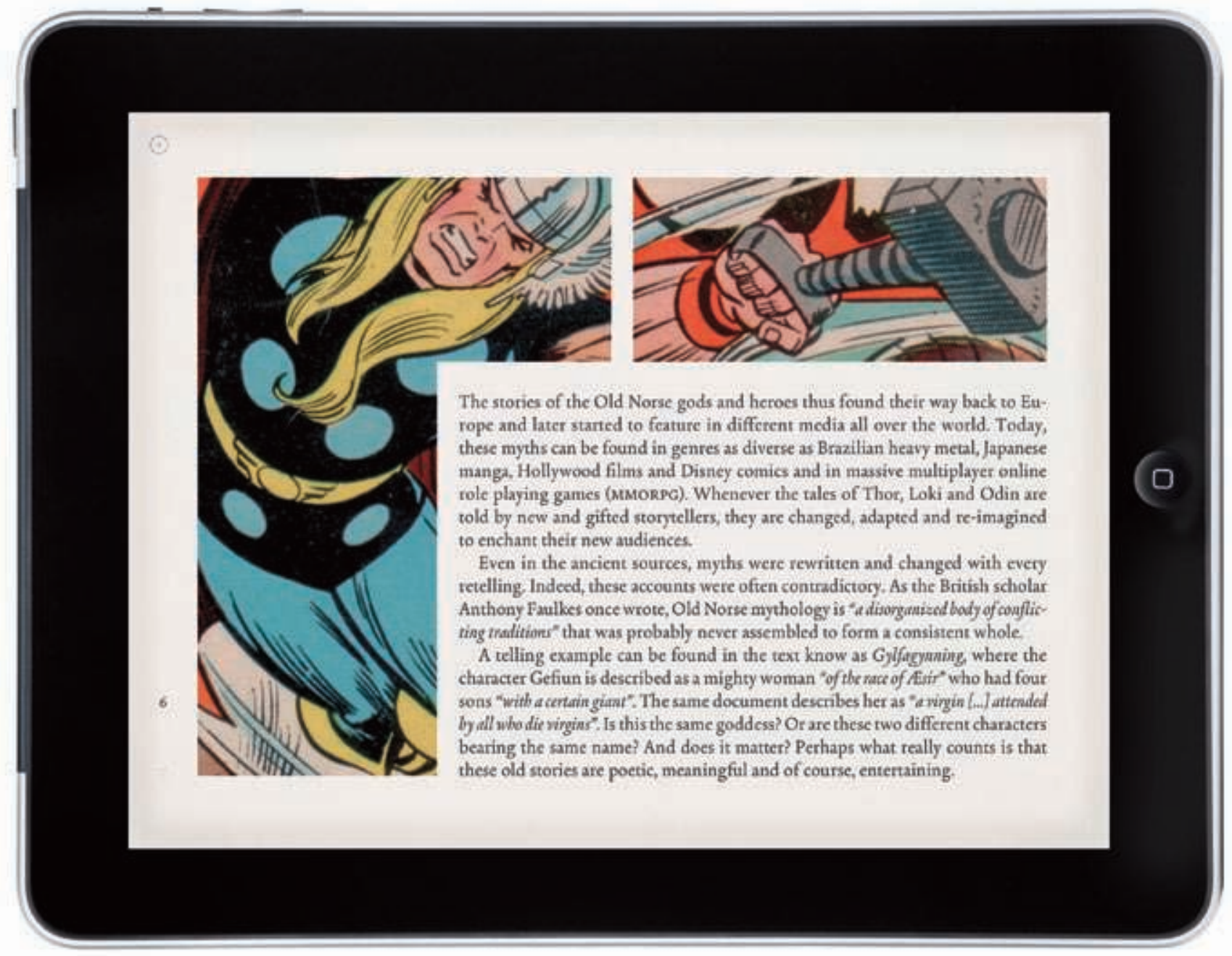




\title{
La mythologie nordique au bout des doigts :
}

\author{
Dreams of Valhalla, une application \\ pour tablette-PG produite à l'Université \\ de Strasbourg
}

Odin, Thor, Loki, Freyja - les dieux nordiques sont de retour partout dans la culture populaire européenne et mondiale. Tolkien et son Seigneur des anneaux, Marvel et son Thor, Wagner avec son Anneau des Nibelungen ont en commun avec des centaines de producteurs de jeux vidéo, de jeux de rôle et de mangas de puiser leur inspiration dans les contes et légendes de l'ancienne Scandinavie.

Bien entendu, ces mythes nordiques ont changé depuis. Les dieux des Vikings ne sont plus les mêmes. Après la fin de l'époque où ils ont accompagné les anciens hommes du Nord, commerçants ou pirates, dans leurs voyages vers l'est et l'ouest, les mythes se sont adaptés à de nouveaux contextes religieux et idéologiques - et à de nouveaux médias : manuscrit sur parchemin ou papier au moyen-âge, livre imprimé, peinture de chevalet, théâtre, opéra, film, bande dessinée... Sous quels avatars vont-ils maintenant apparaître au bout de leur voyage dans les tablettes-PC ?

La meilleure façon de s'approprier cette dernière question reste l'expérience concrète, c'est-à-dire la tentative de transférer ces mythes soimême sur la tablette. Sous la direction scientifique de Thomas Mohnike et l'accompagnement technique et éditorial de Wouter van der Veen et Loïc Sander, une équipe interdisciplinaire de chercheurs de l'Université de Strasbourg a produit la première application iPad sur les mythes nordiques, de leurs origines à leur actualité. Elle compte plus de 250 pages, 55 minutes de vidéo, des centaines d'illustrations, des reproductions spectaculaires de manuscrits anciens et des éléments interactifs innovants. Réalisée en partenariat avec le Musée national du Danemark et l'Institut Árni Magnússon, elle est disponible dès maintenant sur iTunes, en langue anglaise.

Les pages qui suivent donnent quelques exemples de son contenu. 


\section{Ásgard}

Asgard is the land of the fisit Surtounded by a huge wall, it is situated either in Midgard or in a realm of its own, as implied by Snorri. The two realms are connected by the rainbow bridge Bifrost and separated from jotunheimar by woods and a rushing river known as lfing There are many beautiful buildings in Asgard, of which the most fumous is probably Valhalls. According to Snorti, one of the roots of Yggdrasil - the sacred tree that stands in Midgard - reaches down to Urdarbrumn, a boly well in Asgard. This is the dwelling place of the Norns named Urd, Verdandi and Skuld. They are female creatures who tepresent the past, pecient and future. In Seorri' Edda, Asgard generally refess to the realm of the gods. This is less often the case in the Poveic Eddar and other sources.
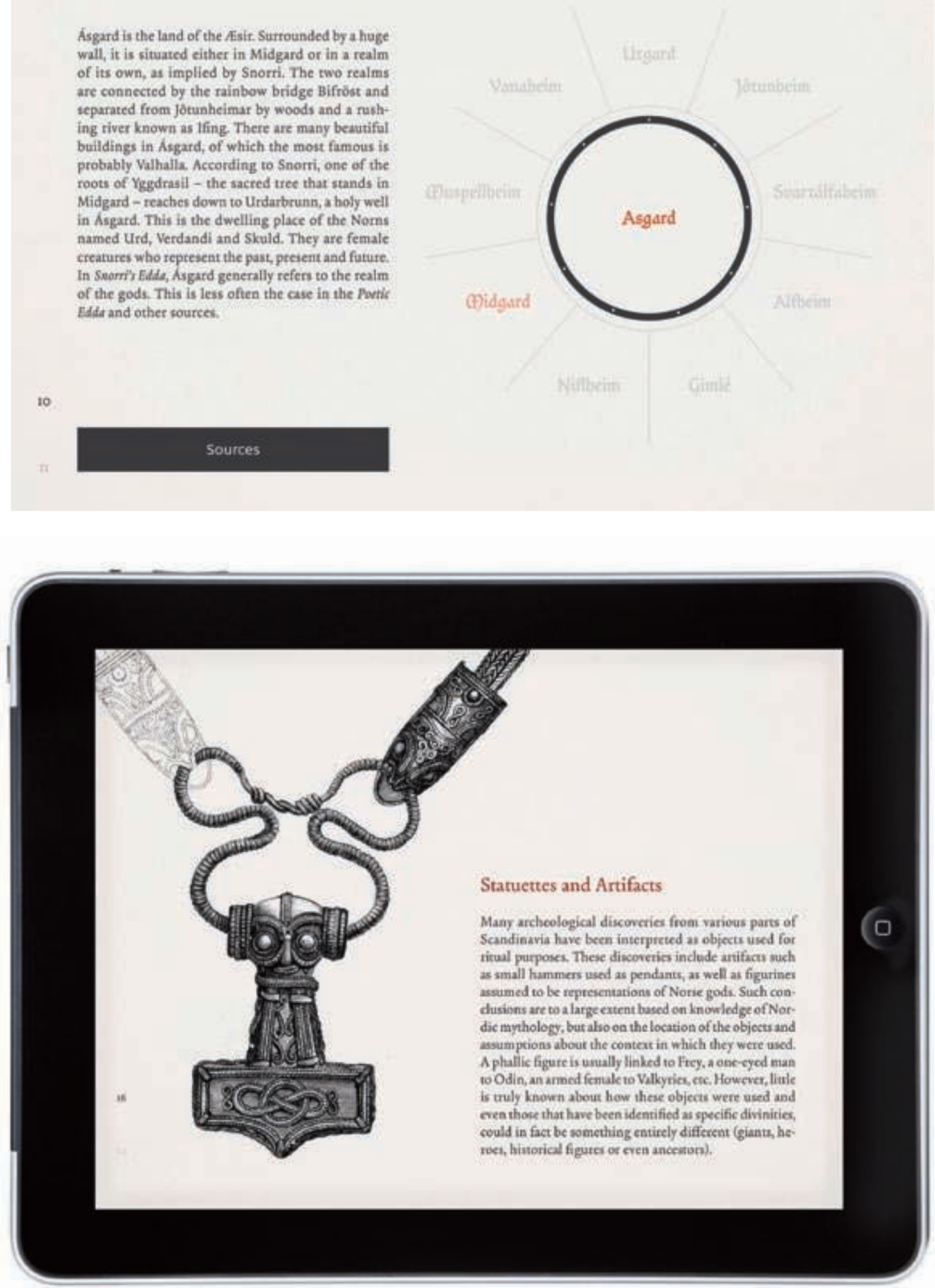

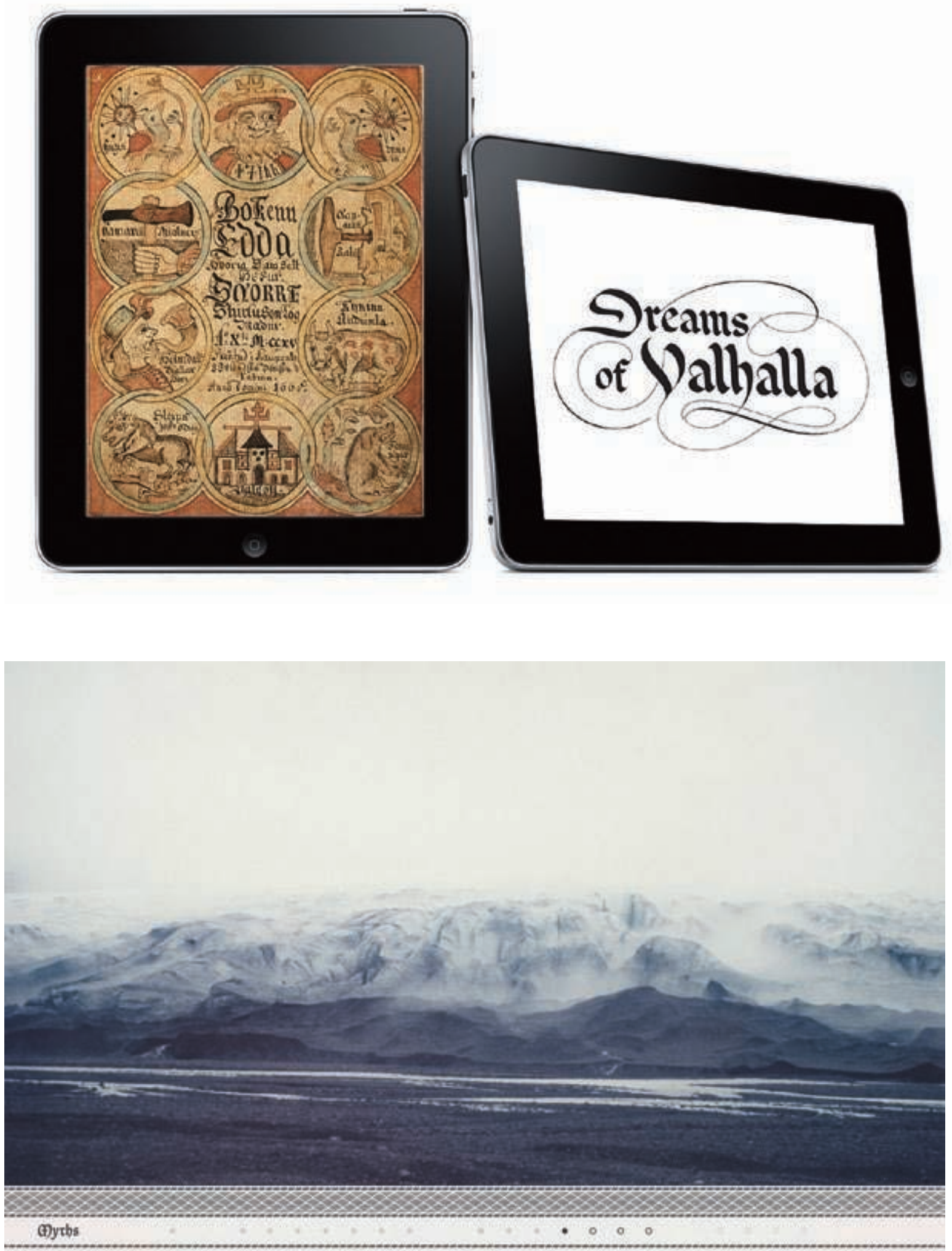

Creation \& Cosmos 